
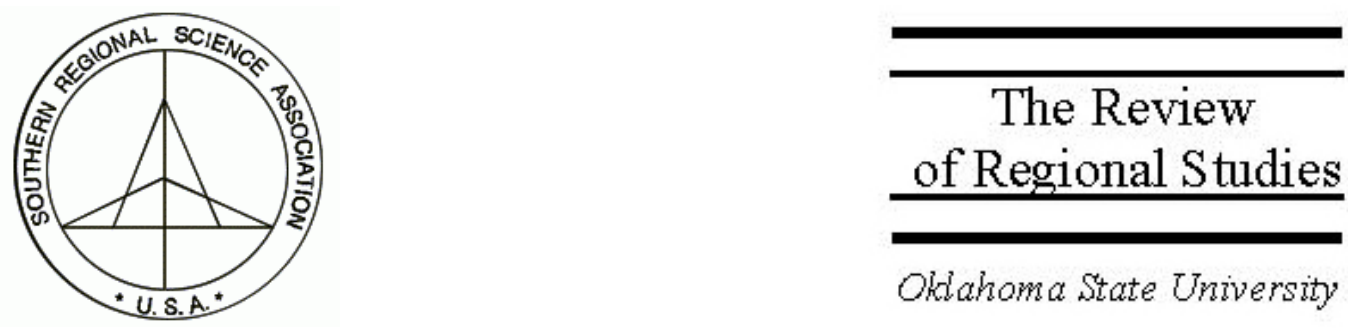

\title{
Intra-NAFTA Trade in Mid-South Industries: A Gravity Model
}

\author{
Mark Funk \\ Department of Economics and Finance, College of Business, University of \\ Arkansas at Little Rock, Little Rock, AR 72204, e-mail: mffunk@ualr.edu \\ Erick Elder \\ Department of Economics and Finance, College of Business, University of \\ Arkansas at Little Rock, Little Rock, AR 72204 \\ Vincent Yao \\ Department of Economics and Finance, College of Business, University of \\ Arkansas at Little Rock, Little Rock, AR 72204 \\ Ashvin Vibhakar \\ Department of Economics and Finance, College of Business, University of \\ Arkansas at Little Rock, Little Rock, AR 72204
}

\begin{abstract}
Using a rich dataset on traffic between members of the North American Free Trade Agreement (NAFTA), this paper examines industry-level trade growth since the implementation of NAFTA for five Mid-South states. Gravity model results show significant disparities across states and industries. For exports within the NAFTA region, the results show large differences in growth rates both between states and between industries. For imports within the NAFTA region, the growth rates vary more between industries than between states. Our results also confirm the importance of intra-industry trade in the U.S.-Mexico trade relationship and suggest a considerable relocation of production linked to trade between NAFTA members.
\end{abstract}

Keywords: NAFTA; Gravity model

JEL classification: R23; R11

The authors thank Mack-Blackwell Rural Transportation Center at the University of Arkansas at Fayetteville for their research support 


\section{INTRODUCTION}

The implementation of NAFTA in January 1994 inspired a large research effort among economists with the aim of measuring the treaty's effects on the three NAFTA economies. Most of the studies used a gravity model approach (Krueger 1999, Gould 1998). Gravity models explain trade flows as a function of the exporter and importer market size and distance from each other. Once these fundamental determinants of trade flows are accounted for, any extraordinary flows can be attributed to free trade agreements or other non-natural features such as borders. For example, both Gould (1998) and Krueger (1999) found that NAFTA does not, in general, have a significant impact on bilateral trade flows, although the increase in trade was net trade creating. Gould came to his conclusion using quarterly data from the three NAFTA countries from 1980 through 1996. Although he concluded that U.S. export growth to Mexico was 16.3 percent higher in the first three years due to the NAFTA treaty, the effects on U.S. imports from Mexico and U.S.-Canada trade were not statistically significant. Krueger used a panel dataset for 61 countries every other year from 1987 to 1997, which enabled her to comment on a broader picture of trade creation and trade diversion effects of NAFTA. Like Gould, she did not find significant trade creation between the NAFTA partners. However, she did find that NAFTA countries import less than predicted from non-NAFTA trading partners.

Like the Gould and Krueger studies, most of the existing literature uses aggregate data and thus overlooks the differences between states, regions, and industries. Not only does this sacrifice valuable information, the aggregated approach prevents economists from drawing clear conclusions for policymakers on the importance of trade within the NAFTA region, especially since policymakers often focus narrowly on specific states or specific industries. For example, the NAFTA-region surface-transported trade grew by 85 percent between 1995 and 2004, but the extra strain on transportation infrastructure was not shared equally across the 50 U.S. states. Moreover, trade in the NAFTA region may have inspired the relocation of production between states. An aggregate analysis would miss the localized effects of the production relocation.

Only a few studies took a more narrow focus. Wall (2003) broke the U.S. into nine BEA economic regions and Canada into three regions and found that the impact of NAFTA differs for different regions. While all U.S. regions except the Rocky Mountains experienced rapid trade growth with Central Canada, most regions experienced declining trade with Eastern and Western Canada. While NAFTA did not affect total trade between the U.S. and Canada, the regional differences were key.

In Wall's study, the South-Central U.S. enjoyed some of the fastest growth in NAFTA trade. This paper examines the growth of trade within the NAFTA region since the implementation of the NAFTA treaty. We narrow the geographic focus to five MidSouth states along one of the NAFTA region's major surface-transported trade routes: Arkansas, Louisiana, Mississippi, Tennessee, and Texas. Note that the states vary substantially by economic size, industrial composition, and trade volume. Table 1 shows the dollar value and the share of total state exports going to Canada and Mexico from our 
sample states. The NAFTA partners are the top two export markets for all states except Louisiana, for whom Canada is the fourth largest market. The share of exports going to Canada and Mexico is 35 percent or greater for four of the states, Louisiana being the exception.

Coughlin and Wall (2003) examined the effects of NAFTA on individual U.S. states. Unlike them, we use data disaggregated to the industry-level (two-digit SIC) and by transportation mode (truck or rail) from the Bureau of Transportation Statistics (BTS). Most industry-level studies focus on describing the data and do not control for other factors as we do with the gravity model (e.g., Burfisher, Robinson, and Thierfelder 2001; Klein, Schuh, and Triest 2002). The few that employ a gravity model focus on only a handful of select industries (e.g., Grant and Lambert 2005). Our previous study (Funk et al. 2006) found striking differences in trade flows across industries and by state. While many industries experienced stable growth of trade within the NAFTA region, other industries saw more dramatic change. Indeed, the considerable differences in the volatility of industry-level trade may dominate the data at the aggregate level. Analysis at the detailed level can account for these industry and state differences and thus should improve the accuracy of the estimates of the NAFTA-area economic relationships.

We find significant disparities across states and industries in the trade flows between NAFTA members. For U.S. state exports to NAFTA partners, the results show large differences in growth rates both between industries and between states. Many industries experienced NAFTA-region export growth in some states while simultaneously shrinking in other states. Variations in import growth within states or within industries are less substantial than the variations in export growth. Once the fundamental determinants of trade are considered, the growth of industry-level NAFTA-region trade in Texas has been weaker than in the other sampled states. Given Texas' central economic position in the NAFTA region, this finding may partially explain the weak aggregate effects of the NAFTA treaty found in the existing literature. Our results also highlight the importance of intra-industry trade. Every state enjoyed increased imports and exports in at least one industry, and two industries showed increased imports and increased exports in at least four states.

TABLE 1

\begin{tabular}{lccccc} 
& \multicolumn{2}{c}{ Exports within NAFTA by State $(2005)$} \\
\hline & \multicolumn{2}{c}{ Total Exports (billions $\$ \mathrm{~s})$} & & \multicolumn{2}{c}{ Share of State Exports } \\
\cline { 2 - 3 } \cline { 5 - 6 } Arkansas & Canada & Mexico & & Canada & Mexico \\
\cline { 2 - 3 } Louisiana & $\$ 1$ & $\$ 0.416$ & & $26 \%$ & $11 \%$ \\
Mississippi & $\$ 1.6$ & $\$ 2.2$ & & $8 \%$ & $11 \%$ \\
Tennessee & $\$ 0.896$ & $\$ 0.535$ & & $22 \%$ & $13 \%$ \\
Texas & $\$ 6.1$ & $\$ 1.9$ & & $32 \%$ & $10 \%$ \\
\hline Source: Origin of Movement State Export Series, Census Bureau & $11 \%$ & $39 \%$ \\
\hline
\end{tabular}


The paper proceeds as follows. Section 2 describes the NAFTA-region industry-level trade patterns using the disaggregated data. We emphasize the inter-industry and interstate disparities in growth and volatility, details that are unavailable in the aggregated data. Section 3 explains the gravity model we use to uncover the NAFTA-region relationships at the disaggregate level. Section 4 reports the estimated gravity models. The results demonstrate that NAFTA-region trade has different growth patterns for different states, industries, and transportation modes. The last section concludes.

\section{NAFTA DATA: A VERY DISAGGREGATED VIEW}

The Bureau of Transportation Statistics (BTS) provides trade data by destination and source in the Transborder Freight Database. The BTS reports the monthly value of NAFTA region trade by transportation mode (truck, rail, mail, and pipe) at the industry level using the two-digit Schedule B industry definition for exports and the two-digit Harmonized Tariff Schedule of the United States Annotated (TSUSA) industry definition for imports, covering 100 industries. We aggregated the data to annual frequency and into 20 two-digit SIC agricultural, mining, and manufacturing industries (see Table 2 for a list of industries).The trade shipped by mail and pipe were dropped from estimation due to the low volume and low frequency of observed trade. The data begins in April 1994, thus limiting our sample of full-year observations to 1995-2004. The BTS data did not account for trans-shipments until 1997. Using the BTS statistics on trans-shipments, we adjust the data for years 1995-1997 to account for trans-shipments. We deflate the trade data using the CPI (2002 base year). A detailed analysis of the data at the various disaggregated levels is provided in Funk et al. (2006).

Aggregating trade across all industries for each state-foreign country combination conceals the substantial variation that exists at the industry level. To illustrate this variation, the third column in Tables $3 \mathrm{a}$ and $3 \mathrm{~b}$ reports the median growth rate across each state's 20 SIC industries for exports and imports respectively. ${ }^{1}$ The state-foreign country combination with the highest median industry growth rate is Tennessee exports to Mexico at 10.7 percent, while the state-foreign country combination with the lowest median industry growth rate is Arkansas exports to Canada (3.2 percent). Even for Arkansas exports to Canada, there is a great deal of variation across industries. The minimum annualized growth rate was -13.6 percent (in SIC 39, Miscellaneous Manufacturing), and the maximum growth rate was 18.1 percent (in SIC 22, Textile Mill Products), with a standard deviation across industries of 7.7 percent - and Arkansas's exports to Canada show relatively little cross-industry variation compared to other states.

\footnotetext{
${ }^{1}$ To estimate the growth and volatility of the disaggregated data series, a log-linear trend was fit through each individual U.S. state-foreign country-mode-industry series:

$$
y_{t}=\alpha+\beta * \text { time }+\varepsilon_{t}
$$

where $y_{t}$ is the log of the particular trade flow. The estimated average annual growth rate of the actual trade flow is then given by $100 *\left(e^{\beta}-1\right)$. For each industry within a given combination the above regression is estimated, the estimated trend growth rate is determined for each industry, and the residuals are obtained.
} 
Mississippi exports to Mexico show annual industry-level growth rates ranging from -19.5 percent to 68.2 percent with a standard deviation of 21.6 percent.

Imports exhibit similar variation. The median industry growth rate of Mississippi imports from Mexico is -1.3 percent, but with wide variation across industries: SIC 38, Instruments and Related Products, shrank an average -39 percent per year while SIC 24, Lumber and Wood Products, grew an average 48.2 percent per year. The state-foreign country combination with the highest median industry growth rate is Louisiana imports from Mexico (13.0 percent overall), with industry growth rates ranging from -14.7 percent (SIC 20, Food and Kindred Products) to 60.6 percent (SIC 37, Transportation Equipment). Finally, notice the fastest growing and the slowest growing industries varied from state to state and by NAFTA partner. Aggregation over industries or over states masks these details that are central to state and regional policymakers.

The volatility of industry-level trade also varied state by state and by NAFTA partner. Tables $3 \mathrm{c}$ and $3 \mathrm{~d}$ show the volatility of exports and imports for each state-foreign country combination. The volatility of a particular series is measured as the average absolute percentage deviation from a log-linear trend. Note that our measure of volatility is the variation around the trend, so trade growing at a high but constant rate would have volatility of zero. The volatility measures how consistent (and thus predictable) the trade

\section{TABLE 2}

\begin{tabular}{rll} 
& \multicolumn{1}{c}{ SIC Industries } \\
\cline { 2 - 2 } SIC & & Industry \\
20 & & Agriculture \\
21 & & Tood and Kindred Products \\
22 & & Textile Mill Products \\
23 & & Apparel and other Textile Products \\
24 & & Lumber and Wood Products \\
25 & & Furniture and Fixtures \\
26 & & Paper and Allied Products \\
28 & & Chemicals and Allied Products \\
30 & & Rubber and Miscellaneous \\
31 & & Leather and Leather Products \\
32 & & Stone, Clay, Glass, and Concrete \\
33 & & Primary Metal Industries \\
34 & & Fabricated Metal Products \\
35 & & Industrial Machinery and Equipment \\
36 & & Electrical and Electronic Equipment \\
37 & & Transportation Equipment \\
38 & & Instruments and Related Products \\
39 & Miscellaneous Manufacturing \\
\hline
\end{tabular}


The Review of Regional Studies, Vol. 36, No. 2, 2006, pp. 205-220

TABLE 3a

Export Growth by Country

\begin{tabular}{ccrrrrrc}
\hline State & Country & Median & STD & Min & Max & Min SIC & Max SIC \\
\hline AR & Mexico & 4.0 & 16.7 & -28.6 & 31.4 & 31 & 30 \\
AR & Canada & 3.2 & 7.7 & -13.6 & 18.1 & 39 & 22 \\
LA & Mexico & 10.3 & 12.9 & -19.2 & 37.0 & 36 & 10 \\
LA & Canada & 3.4 & 14.2 & -8.8 & 44.0 & 39 & 23 \\
MS & Mexico & 8.7 & 21.6 & -19.5 & 68.2 & 36 & 20 \\
MS & Canada & 4.2 & 11.3 & -9.3 & 43.1 & 39 & 10 \\
TN & Mexico & 10.7 & 12.4 & -15.4 & 36.0 & 24 & 25 \\
TN & Canada & 4.5 & 6.9 & -7.3 & 18.8 & 1 & 38 \\
TX & Mexico & 4.6 & 7.2 & -13.1 & 12.4 & 21 & 35 \\
TX & Canada & 3.6 & 5.7 & -9.6 & 19.8 & 39 & 25 \\
Maximum & & 10.7 & & & 68.2 & & \\
Minimum & & 3.2 & & -28.6 & & & \\
\hline
\end{tabular}

TABLE $3 b$

Import Growth by Country

\begin{tabular}{ccrrrrrc}
\hline State & Country & Median & STD & Min & Max & Min SIC & Max SIC \\
\hline AR & Mexico & 5.4 & 12.8 & -16.7 & 36.7 & 1 & 30 \\
AR & Canada & 5.2 & 8.9 & -6.8 & 26.1 & 37 & 1 \\
LA & Mexico & 13.0 & 20.1 & -14.7 & 60.6 & 20 & 37 \\
LA & Canada & 4.4 & 8.0 & -3.4 & 22.6 & 32 & 23 \\
MS & Mexico & -1.3 & 22.0 & -39.0 & 48.2 & 38 & 24 \\
MS & Canada & 6.0 & 8.8 & -4.4 & 23.0 & 32 & 23 \\
TN & Mexico & 11.3 & 20.1 & -13.1 & 65.7 & 24 & 22 \\
TN & Canada & 6.3 & 15.3 & -4.4 & 68.9 & 22 & 21 \\
TX & Mexico & 4.5 & 6.6 & -7.7 & 17.4 & 24 & 35 \\
TX & Canada & 7.5 & 6.4 & 0.6 & 24.3 & 36 & 22 \\
Maximum & & 13.0 & & & 68.9 & & \\
Minimum & & -1.3 & & -39.0 & & & \\
\hline
\end{tabular}

flows are over time. We find that there is a considerable amount of volatility over time for many of the industries. The least volatile export series is for SIC 28, Chemicals and Allied Products, from Tennessee to Canada where the average absolute percentage deviation is only 3.9 percent. The column labeled "Median" reports the median volatility measure over all of the industries for a particular state-country combination. The median export (and import) volatility is generally less than 20 percent for all states' trade with Canada, but is over 30 percent for all states' (except Texas) trade with Mexico, suggesting that for many industries trade with Mexico has been much more volatile than trade with Canada since the implementation of the NAFTA treaty. 
TABLE 3c

Export Volatility by Country

\begin{tabular}{cccrrrrc}
\hline State & Country & Median & STD & Min & Max & Min SIC & Max SIC \\
\hline AR & Mexico & 45.7 & 49.3 & 17.1 & 212.1 & 33 & 10 \\
AR & Canada & 16.6 & 7.4 & 10.1 & 37.8 & 30 & 10 \\
LA & Mexico & 40.4 & 22.2 & 11.4 & 98.5 & 30 & 34 \\
LA & Canada & 15.1 & 19.7 & 5.5 & 88.1 & 31 & 23 \\
MS & Mexico & 58.0 & 45.9 & 15.3 & 201.2 & 28 & 36 \\
MS & Canada & 16.9 & 16.6 & 8.5 & 84.7 & 34 & 37 \\
TN & Mexico & 33.2 & 20.3 & 9.4 & 81.6 & 28 & 10 \\
TN & Canada & 15.4 & 12.5 & 3.9 & 54.8 & 28 & 39 \\
TX & Mexico & 14.7 & 10.4 & 6.2 & 50.8 & 1 & 21 \\
TX & Canada & 12.2 & 5.2 & 7.2 & 26.5 & 1 & 37 \\
Maximum & & 58.0 & & & 212.1 & & \\
Minimum & & 12.2 & & 3.9 & & & \\
\hline
\end{tabular}

TABLE 3d

Import Volatility by Country

\begin{tabular}{ccccrrcc}
\hline State & Country & Median & \multicolumn{1}{c}{ STD } & Min & Max & Min SIC & Max SIC \\
\hline AR & Mexico & 46.7 & 55.4 & 10.2 & 248.9 & 20 & 37 \\
AR & Canada & 16.7 & 11.7 & 8.6 & 42.2 & 35 & 38 \\
LA & Mexico & 56.4 & 132.1 & 12.4 & 578.3 & 35 & 37 \\
LA & Canada & 18.3 & 11.5 & 8.7 & 56.3 & 33 & 34 \\
MS & Mexico & 63.0 & 42.6 & 21.8 & 205.3 & 32 & 37 \\
MS & Canada & 19.0 & 14.5 & 4.3 & 58.5 & 24 & 23 \\
TN & Mexico & 31.6 & 12.9 & 18.1 & 69.8 & 33 & 24 \\
TN & Canada & 15.9 & 22.3 & 5.9 & 108.3 & 35 & 21 \\
TX & Mexico & 10.6 & 12.6 & 4.4 & 58.5 & 39 & 10 \\
TX & Canada & 12.6 & 5.7 & 3.9 & 29.1 & 20 & 36 \\
Maximum & & 63.0 & & & 578.3 & & \\
Minimum & & 10.6 & & 3.9 & & & \\
\hline
\end{tabular}

\section{METHODOLOGY}

While economic theory explains trade flows as arising from comparative advantage or economies of scale, empirical researchers have found that a simple gravity model outperforms traditional theory-based empirical specifications. Anderson and Wincoop (2003) provide a good overview of the motivation and empirical use of the gravity model. The basic gravity model explains (natural) trade patterns as resulting from economic size (income and population) and distance. The impact of unnatural factors such as trade or security policies can be tested by adding proxies to the model. In a panel setting, the time-invariant distance effect cannot be distinguished from the time-invariant fixed effect or other time-invariant factors such as border effects or language. Several solutions have been proposed that allow the disentangling of the effects of time-invariant factors. 
Anderson and Wincoop (2003) suggest using a multilateral resistance term. Chang and Wall (2004) suggest a two-stage estimation process: estimate an importer-exporter fixed effect in the first stage, then regress the fixed effect on distance and other time-invariant factors in the second stage. The Chang and Wall method has the advantages of being estimable via ordinary least squares and of not requiring the assumptions about distance internal to states and countries. We adopt the Chang and Wall fixed-effects gravity model method. In the simplest specification, the gravity model explains bilateral trade flows as a function of the exporter and importer per capita GDP, a time effect, and a fixed effect for each exporter-importer pair. The time-invariant fixed effect captures all time-invariant effects such as distance, borders effects, and language. Since we are not directly interested in these effects, we do not estimate the second stage.

Previous gravity models of NAFTA aggregated trade flows over industries or states. We disaggregate data into 20 two-digit SIC industries. Further, this paper evaluates trade flows disaggregated by the mode of transportation. Extending the Chang and Wall (2004) specification to our context, we model the trade flow of industry $k$ from U.S. state $i$ to NAFTA trade partner $j$ as:

$$
X_{i j k}=\alpha_{i j}+\beta_{1} G S P C_{i}+\beta_{2} G D P C_{j}+\delta_{1} \text { Trend }+\varepsilon_{i j}
$$

where $X_{i j k}$ is the $\log$ of exports, $G S P C_{i t}$ is the $\log$ per capita gross state product of state $i$, $G D P C_{j t}$ is the $\log$ of per capita foreign gross domestic for foreign country $j$, and Trend denotes the time trend (excluding a time subscript for notational convenience). The above specification of the gravity model assumes that each exporter-importer pair has a unique intercept $\left(\alpha_{i j}\right)$, but that all industries within a given exporter-importer pair share the same intercept. This implies that for a given exporter-importer pair such as Arkansas and Mexico, the predicted trade volumes would be identical for all industries. To allow industries to have different intercepts and thus differing trade volumes, we also incorporate an industry-specific intercept. Equation (1) also assumes a common time trend for all industries for any exporter-importer pair. This implies that for a given exporter-importer pair such as Arkansas and Mexico, the growth rate of trade would be identical across all industries. In the estimation, we can also allow for unique trends for each industry. Our gravity model specification thus becomes:

$$
\ln X_{i j k}=\alpha_{i j}+\alpha_{k}+\beta_{1} G S P C_{i}+\beta_{2} G D P C_{j}+\delta_{1} \text { Trend } * S I C+\varepsilon_{i j}
$$

where $\alpha_{k}$ is the industry-specific intercept and SIC is a vector of industry dummies allowing the estimation of industry-specific trends. Note that the industry-specific intercept $\alpha_{k}$ is constant across NAFTA trade partners. We estimate Equation (2) separately for each state. In the estimation, the $\alpha_{i j}$ term reduces to a dummy with a value of 1 if the NAFTA partner is Canada and 0 if the partner is Mexico. The estimated industry-level trend shows the industry-level growth of NAFTA region trade not captured by the fundamental determinants of trade such as the growth in domestic and foreign per capita GDP and the country dummy. 
The size of each state's economy comes from the Bureau of Economic Analysis' (BEA) Gross State Product (GSP). Canadian GDP and population data come from Statistics Canada. Mexican GDP and population data come from the IMF's World Economic Outlook. The GDP data is converted to PPP US\$ (2002 \$) using the IMF's PPP exchange rates from the IMF's World Economic Outlook.

\section{GRAVITY MODEL}

Using the BTS data, we estimate the gravity model specified in Equation (2) by Feasible Generalized Least Square (FGLS). The error term in Equation (2), $\varepsilon_{i j}$, is assumed to include two error components: one fixed effects and the other white noise. Therefore, FGLS estimates a fixed-effects panel data model (Baltagi 2001). Coefficients on industry-specific trends are the most interesting to us. Previous studies, such as Gould (1998) and Krueger (1999), usually test the significance of a NAFTA dummy (before and after 1994) impacting gross output. But as Burfisher, Robinson, and Thierfelder (2001) point out, both the static and dynamic benefits of free trade are realized through economic adjustment, as trading partners reallocate resources to their industries of comparative advantages. With the disaggregated data, we are able to describe the evolving lifecycle of different industries for each state as the adjustment to the NAFTA treaty progresses. With income and other trade determinants accounted for by the gravity model, the industryspecific trend coefficients capture each industry's growth rate of NAFTA region trade. Rather than measuring the impact of the NAFTA treaty on trade as in previous studies, our focus is on understanding industry-level trade growth since the implementation of the NAFTA treaty.

\subsection{Exports}

We estimate the gravity model for each state and for imports and exports separately to obtain a clearer picture of the underlying dynamics of trade with NAFTA partners in the Mid-South states. The estimation includes a constant, state gross state product (GSP), foreign GDP, a country dummy, industry fixed-effects (base industry is SIC 39, Miscellaneous Products), and industry-specific trends. ${ }^{2}$ Table $4 a$ reports results from the gravity model when exports is the dependent variable.

The effect of state-level GSP and foreign country GDP on state exports differs across states. All states show a statistically significant positive relationship between foreign per capita GDP and state exports. The relationship varies from a low of 1.17 for Texas to 4.32 in Mississippi. The results for per capita state GSP show even more disparity of

\footnotetext{
${ }^{2}$ Tennessee reported exports in all 20 industries, while the other four states reported exports in only 19 industries (SIC 21, Tobacco Products, being the difference). For Tennessee, the regressions include 19 fixed effects and 20 industry trends. For the other states, the regressions include 18 fixed effects and 19 industry trends. Note that the results are identical if, for Tennessee, we had estimated 19 industry trends plus a trend for the model. The trends in the state and foreign country GDP were removed prior to estimation.
} 
state's responses. The estimated elasticity for exports to GSP is the highest at 4.43 for Arkansas and the lowest at -2.10 for Louisiana (both statistically significant at the 5 percent level). The divergent responses may reflect different business cycles at the state level, as analyzed in Owyang, Piger and Wall (2005). For example, the five states experienced different duration and depth of contractions during the most recent recession. Holding all else constant, all five states would export more to Mexico than to Canada.

Our data and specification allow us to estimate unique growth trends for each industry in each state since the implementation of NAFTA, with the fundamental trade determinants captured by the gravity model. Examining the data within states, the industrylevel trends show striking variance. Tennessee had more industries (13 of 20) exhibiting statistically significant trend growth than the other four states. Tennessee's fastest

TABLE 4a

\begin{tabular}{|c|c|c|c|c|c|}
\hline \multicolumn{6}{|c|}{ Exports } \\
\hline & Arkansas & Louisiana & Mississippi & Tennessee & Texas \\
\hline FGDPC & $3.02^{* *}$ & $2.66^{* *}$ & $4.32^{* * *}$ & $3.39^{* *}$ & $1.17^{* *}$ \\
\hline GSPC & $4.43^{* *}$ & $-2.10^{* *}$ & $0.47^{* *}$ & $2.97^{* *}$ & $3.96^{* *}$ \\
\hline CanDummy & $-2.01^{*}$ & $-2.10^{*}$ & $-3.98^{* *}$ & $-2.69^{* *}$ & $-3.17^{* *}$ \\
\hline SIC 01-09 & 0.04 & 0.02 & $0.10^{* *}$ & 0.03 & $0.04^{*}$ \\
\hline SIC 10-14 & $-0.13^{* *}$ & $0.20^{* *}$ & $0.34^{* *}$ & -0.02 & 0.02 \\
\hline SIC 20 & $0.07^{* *}$ & $0.12^{* *}$ & 0.03 & 0.02 & $0.06^{* *}$ \\
\hline SIC 21 & -- & -- & -- & $-2.00^{* *}$ & -- \\
\hline SIC 22 & $0.10^{*}$ & $0.06^{* *}$ & 0.06 & $0.08^{* *}$ & 0.07 \\
\hline SIC 23 & -0.10 & 0.10 & -0.00 & -0.03 & -0.00 \\
\hline SIC 24 & -0.02 & -0.05 & 0.02 & -0.03 & 0.02 \\
\hline SIC 25 & 0.01 & $0.07^{*}$ & 0.11 & $0.14^{*}$ & 0.04 \\
\hline SIC 26 & $0.12^{* *}$ & 0.05 & -0.03 & 0.04 & $0.03^{*}$ \\
\hline SIC 28 & 0.00 & $0.04^{*}$ & 0.01 & $0.04^{* *}$ & 0.04 \\
\hline SIC 30 & $0.16^{* *}$ & $0.12^{* *}$ & $0.16^{* *}$ & $0.06^{* *}$ & $0.08^{* *}$ \\
\hline SIC 31 & -0.09 & 0.09 & $0.18^{* *}$ & $0.14^{* *}$ & 0.02 \\
\hline SIC 32 & 0.04 & 0.01 & 0.06 & $0.04^{*}$ & $0.04^{* *}$ \\
\hline SIC 33 & $0.06^{* *}$ & 0.01 & $0.04^{*}$ & $0.10^{*}$ & $0.04^{* *}$ \\
\hline SIC 34 & $-0.07^{* *}$ & $0.24^{* *}$ & 0.01 & $0.14^{*}$ & 0.01 \\
\hline SIC 35 & 0.04 & $0.06^{* *}$ & 0.02 & $0.10^{* *}$ & $0.08^{*}$ \\
\hline SIC 36 & -0.02 & $-0.10^{* *}$ & -0.05 & $0.10^{* *}$ & $0.05^{* *}$ \\
\hline SIC 37 & 0.02 & 0.09 & $0.17^{* *}$ & $0.07^{* *}$ & $0.06^{* *}$ \\
\hline SIC 38 & 0.03 & 0.01 & 0.04 & $0.22^{* *}$ & $0.07^{* *}$ \\
\hline SIC 39 & $-0.21^{* *}$ & -0.13 & $-0.08^{*}$ & 0.08 & -0.04 \\
\hline $\begin{array}{l}\text { F-test } \\
\text { on industries }\end{array}$ & 33.14 & 38.58 & 17.89 & 87.49 & 52.88 \\
\hline $\mathrm{R}_{\text {adj }}^{2}$ & 0.60 & 0.66 & 0.48 & 0.81 & 0.57 \\
\hline $\begin{array}{l}* *=\text { significar } \\
\text { hypothesis is a } \\
\text { intercepts and } \\
0 \text { if Mexico, } 1\end{array}$ & $\begin{array}{l}5 \% \text { level; } \\
\text { mon trend a } \\
\text { s. FGDPC } \\
\text { hada. }\end{array}$ & $\begin{array}{l}\text { gnificant a } \\
\text { ercept acr } \\
\text { apita coun } \\
\end{array}$ & $\begin{array}{l}\text { level. F-st } \\
\text { ustries vers } \\
\text { PP; GSPC }\end{array}$ & $\begin{array}{l}\text { e test statis } \\
\text { alternative o } \\
\text { apita state } G\end{array}$ & $\begin{array}{l}\text { here the nu } \\
\text { istry specifi } \\
\text { anDummy }\end{array}$ \\
\hline
\end{tabular}


growing industry once the fundamental trade determinants are captured by the gravity model is SIC 38 (Instruments and Related Products), with an annual growth rate of 0.22. Aside from SIC 21 (Tobacco), the slowest statistically significant growth among Tennessee's industries occurred in SIC 28 (Chemicals and Allied Products) and SIC 32 (Stone, Clay, Glass, and Concrete), with annual growth of 0.04. Only seven Mississippi industries show statistically significantly growth trends. Mississippi's SIC 10-14 (Mining) industry grew at an annual rate of 0.34 , which is the fastest growth of any industry in any of the five states, but SIC 39 (Miscellaneous Products) grew at -0.08 . Eight Arkansas industries showed statistically significant trends, with five of the industries showing positive growth and three industries shrinking. Nine Louisiana industries showed statistically significant growth in exports to NAFTA partners, from SIC 34 (Fabricated Metal Products) growing at a 0.24 annual rate to SIC 36 (Electrical and Electronic Equipment) growing at a -0.10 annual rate. The widely divergent export growth rates since the implementation of the NAFTA treaty on industries within individual states suggest future researchers should carefully consider the variations between industries. Only Texas breaks the mold: statistically significant industry growth trends in Texas range from 0.03 (SIC 26, Paper and Allied Products) to 0.08 (SIC 30, Rubber Products, and SIC 35, Industrial Machinery). By absolute dollar terms, Texas has more trade volume and gained more trade volume with NAFTA partners than any other state in the nation. Since Texas would dominate any aggregation over states, aggregate analysis may not reveal the substantial variation between industries within states that is shown by our disaggregated analysis.

The disaggregated analysis within industries is also revealing. Some industries showed commonalities across states. Of the 20 industries, 11 industries showed positive growth rates in all five states. Only SIC 30 (Rubber and Miscellaneous) showed positive, statistically significant trend growth in all five states, with growth ranging from 0.06 in Tennessee to 0.16 in Arkansas and Mississippi. Only SIC 33 (Primary Metal Industries) showed positive, statistically significant growth in four states.

More interestingly, for many industries exports to NAFTA partners grew in some states while simultaneously shrinking in other states. For example, SIC 36 (Electrical and Electronic Equipment) exports grew in Tennessee and Texas (statistically significant estimated trends of 0.10 and 0.05 , respectively) but shrank in the other three states with a statistically significant estimated trend of -0.10 in Louisiana. SIC 10-14 (Mining) had statistically significant positive export growth in Louisiana and Mississippi ( 0.20 and 0.34 , respectively) but statistically significant falling exports from Arkansas (-0.13). SIC 34 (Fabricated Metal Products) exports to NAFTA partners grew in Tennessee and Louisiana but shrank in Arkansas. These results imply that the variations between industries may be less significant than variations between states within industries, which suggests that researchers should pay more attention to state differences than industry differences. The results may indicate the relocation of production as the international trade forces a reallocation of resources. Note that aggregating across states would yield results similar to Texas's results, given Texas's dominant share of the trade in the NAFTA region. Since the industry-level trends in Texas are weak compared to the other states, 
analysts may not find the industry-level effects unless the data is disaggregated to the state level.

\subsection{Imports}

Table $4 \mathrm{~b}$ provides the gravity model results for imports. The effects on imports of foreign per capita GDP, per capita GSP, and Canadian dummy are quite different from those on exports. Most of the gravity model coefficients are positive, but only Tennessee's results are statistically significant. This suggests that per capita output is not a primary driver of state imports from NAFTA partners. Texas and Tennessee are significantly more likely to import from Mexico than Canada. The other states are more likely to import from Canada than Mexico, but the effect is statistically significant only for Louisiana.

The industry-specific import trends vary within each state, but less so than with exports. More Tennessee industries (11) showed statistically significant growth in imports to NAFTA partners than in any other state, while only five Mississippi industries showed statistically significant growth. The trends in Tennessee industries range from .05 in SIC 39 (Miscellaneous Products) to 0.28 in SIC 20 (Food and Kindred Products). The statistically significant trends in Mississippi range from 0.11 in SIC 22 (Textile Mill Products) to 0.20 in SIC 24 (Lumber and Wood Products). In Arkansas, the statistically significant trends range from 0.06 in SIC 24 (Lumber and Wood Products) to 0.18 in SIC 10-14 (Mining). The range of estimated trend growth rates in Louisiana started at 0.05 in SIC 10-14 (Mining) to 0.27 in SIC 34 (Fabricated Metal Products). In Texas, the statistically significant trends ranged from 0.03 in SIC 33 (Primary Metal Industries) to 0.13 in SIC 22 (Textile Mill Products). No industry in any state exhibited statistically significantly negative growth in imports to NAFTA partners once the gravity model accounted for the fundamental determinants of growth.

Most industries also show less import-growth variation across states than exportgrowth variation. For example, the growth of SIC 34 (Fabricated Metal Products) exports to NAFTA partners ranged from -0.07 to 0.24 , but growth of import from NAFTA partners ranged from 0.11 to 0.27 . Only two industries saw statistically significant positive export growth in at least four states; four industries saw statistically significant positive import growth in at least four states; three industries saw exports shrink in some states while increasing in others; no industry saw statistically significant decrease in imports in any state.

Texas' growth of trade with NAFTA partners has been much smaller than in the other states, possibly because Mexico-Texas trade reached maturity in anticipation of the NAFTA treaty. Again, given the dominant trade volume in Texas, aggregating across states would yield results similar to Texas. Since the industry-level trends in Texas are much weaker, economically and statistically, than in the other states, the industry-level effects may not be visible unless the data are disaggregated to the state level. 
TABLE $4 \mathrm{~b}$

\begin{tabular}{|c|c|c|c|c|c|}
\hline \multicolumn{6}{|c|}{ Imports } \\
\hline & Arkansas & Louisiana & Mississippi & Tennessee & Texas \\
\hline FGDPC & 0.95 & -1.18 & 0.68 & $2.86^{* *}$ & 0.91 \\
\hline GSPC & 1.09 & 1.11 & 2.69 & $3.14^{* *}$ & 1.24 \\
\hline CanDummy & 0.34 & $4.06^{* *}$ & 0.99 & $-2.37^{*}$ & $-2.31^{* *}$ \\
\hline SIC 01-09 & 0.08 & 0.07 & 0.07 & 0.04 & 0.04 \\
\hline SIC $10-14$ & $0.18^{* *}$ & $0.05^{* *}$ & 0.04 & 0.04 & 0.06 \\
\hline SIC 20 & 0.09 & -0.01 & 0.01 & $0.28^{* *}$ & $0.12^{* *}$ \\
\hline SIC 21 & -- & -- & -- & $0.51^{* *}$ & -- \\
\hline SIC 22 & 0.01 & 0.08 & $0.11^{*}$ & $0.23^{* *}$ & $0.13^{* *}$ \\
\hline SIC 23 & 0.06 & 0.12 & 0.06 & 0.12 & 0.02 \\
\hline SIC 24 & $0.06^{* *}$ & 0.00 & $0.20^{* *}$ & -0.05 & -0.01 \\
\hline SIC 25 & $0.08^{* *}$ & $0.10^{* *}$ & 0.05 & $0.13^{* *}$ & $0.11^{* *}$ \\
\hline SIC 26 & 0.06 & -0.06 & 0.06 & 0.03 & 0.03 \\
\hline SIC 28 & $0.16^{* *}$ & $0.15^{* *}$ & $0.19^{* *}$ & $0.15^{* *}$ & 0.06 \\
\hline SIC 30 & $0.14^{* *}$ & $0.11^{* *}$ & $0.12^{* *}$ & $0.06^{* *}$ & 0.03 \\
\hline SIC 31 & -0.05 & 0.05 & -0.09 & $0.07^{* *}$ & -0.02 \\
\hline SIC 32 & $0.12^{* *}$ & 0.04 & 0.05 & 0.03 & 0.07 \\
\hline SIC 33 & $0.13^{*}$ & 0.01 & -0.07 & $0.12^{* *}$ & $0.03^{* *}$ \\
\hline SIC 34 & $0.15^{* *}$ & $0.27^{* *}$ & 0.02 & $0.14^{*}$ & $0.11^{* *}$ \\
\hline SIC 35 & 0.01 & $0.09^{* *}$ & $0.12^{* *}$ & 0.10 & $0.12^{* *}$ \\
\hline SIC 36 & 0.03 & 0.01 & 0.02 & -0.01 & 0.04 \\
\hline SIC 37 & -0.04 & 0.12 & 0.05 & 0.05 & $0.09^{* *}$ \\
\hline SIC 38 & 0.03 & $0.23^{*}$ & -0.13 & $0.21^{* *}$ & 0.03 \\
\hline SIC 39 & 0.01 & $0.05^{*}$ & 0.04 & $0.05^{* *}$ & $0.09^{* *}$ \\
\hline $\begin{array}{l}\text { F test } \\
\text { on industries }\end{array}$ & 10.76 & 8.00 & 9.92 & 12.89 & 14.96 \\
\hline $\mathrm{R}_{\text {adj }}^{2}$ & 0.58 & 0.78 & 0.72 & 0.70 & 0.37 \\
\hline
\end{tabular}

A comparison between Tables $4 \mathrm{a}$ and $4 \mathrm{~b}$ allows us to evaluate the importance of vertical intra-industry trade (IIT) in the U.S.-Mexico trade relationship. The U.S. International Trade Commission (1997), Gonzalez and Velez (1995), and others find that trade between Mexico and the U.S. features significant levels of assembly and other valueadded activities of U.S. components in Mexico for re-export to the U.S. Every state enjoyed increased imports and exports in at least one industry, with five Louisiana industries and eight Tennessee industries showing growth in both imports and exports. SIC 30 (Rubber and Miscellaneous) and SIC 33 (Primary Products) showed both import and export growth in four of the five states.

We also estimated the gravity model for each state by each mode (truck and rail) for exports and imports separately (results available from the authors). The results were qualitatively similar to the gravity model aggregated over modes, with one additional insight: exports transported by rail have markedly different reactions to per capita GDP 
when the compared to truck-transported exports. For truck exports, all states had positive estimated reactions to foreign GDP, with three of the five states having statistically significant responses greater than 1.0; for rail exports, the estimated reaction is negative for three of five states and is statistically significant (at the 10 percent level) and positive for only one state (Mississippi). Similarly, the reaction to state GSP is negative for four of five states when the exports are by rail; the reaction to state GSP is positive and statistically significant (at the 5 percent level) for four of the five states for truck exports. These results strongly suggest that rising per capita income in U.S. states and foreign countries leads to a larger share of exports transported by truck.

\subsection{Effect of Accounting for Fundamental Trade Determinants}

Comparison between trends in the raw data and the trends estimated in the gravity models provides further insight into trade within the NAFTA region. The difference between the raw growth rates and the gravity model growth rates indicate the effect of fundamental factors such as per capita GDP. For example, Mississippi imports of SIC 34 (Fabricated Metal Products) show a raw annual growth rate of 0.14 , but once the fundamental trade factors are removed, the gravity model annual growth rate falls 0.02 . Mississippi imports of SIC 35 (Industrial Machinery) show a raw annual growth rate of 0.05 , but once the fundamental trade factors are removed the gravity model annual growth rate increases to 0.12 . In general, the gravity model boosts the estimated import growth in SIC 35 (Industrial Machinery) and SIC 23 (Apparel) but decreases import growth in SIC 01-09 (Agriculture). The gravity model boosts the estimated export growth in SIC 25 (Furniture), SIC 23 (Apparel), and SIC 34 (Fabricated Metal Products) but decreases export growth in SIC 10 (Mining), SIC 24 (Lumber), SIC 20 (Food), and SIC 22 (Textile Mill Products).

The results also point to two industries that had extensive domestic distortions in addition to trade barriers and were often put at the top of the "endangered jobs" list in the pre-NAFTA debate, for instance by Perot and Choate (1993) and Shaiken (1993). One is Agriculture (SIC 01), which accounts for 24 percent of Mexican employment. In general, the raw data show strong positive trends in import growth in agricultural goods. However, fears of too many displaced farm workers and possible migration to Mexican cities and the United States led to the final NAFTA agreement allowing a 15-year transition period for sensitive crops. The transition includes a two-tiered tariff structure for imports from NAFTA partners. Therefore, the full effects of the NAFTA agreement have not yet been felt in this industry; the gravity models find limited negative effects of the NAFTA agreement on the overall agricultural sector to date. Interestingly, Grant and Lambert (2005) find substantial levels of trade creation when they further disaggregate the agricultural sector into nine sectors. The second industry is autos and parts (SIC 37). Many economists (for instance, Womack, 1991) argued that Mexico had extensive distortions in the auto industry through its "auto decrees" that included requirements for domestic content and the trade balance, and therefore the NAFTA treaty would benefit both exports and imports of U.S. auto industry. Burfisher, Robinson, and Thierfelder (2001) find a dramatic increase of intra-industry trade in auto and parts since 1994, and the raw 
data shows positive trends in imports and exports for Louisiana, Mississippi, Tennessee, and Texas. Once the fundamental trade factors are controlled for in the gravity model, the data shows increasing growth of trade with NAFTA partners for Texas, Tennessee, and Mississippi exports and increasing growth of imports for Texas.

\section{CONCLUSION}

Most NAFTA studies use aggregate data and thus sacrifice valuable information on crucial differences between states, regions, and industries. The benefits of free trade, however, are realized through economic adjustment, as trading partners reallocate resources to their industries of comparative advantages. The aggregated approach prevents economists from drawing clear conclusions on the narrow policy issues of most interest to state and regional policymakers. This paper examines industry-level growth since the implementation of NAFTA. With the data disaggregated to the industry and state levels, we are able to describe the evolving life cycles of different industries for each state as the NAFTA adjustment progresses.

Gravity model results show significant disparity of trade between NAFTA members at the state and industry levels. The results show both substantial variation in export growth across states for many industries and substantial variation in export growth within states across industries. This suggests that the inter-industry variations are at least as important as the interstate variations. Variations in imports growth within states or within industries are less substantial than the variations in export growth. These differences would not be visible at aggregated levels.

The data also indicates significant relocation of production within the five sample states. Many industries experienced growth in exports to NAFTA partners in some states while simultaneously shrinking in other states. For example, SIC 36 (Electrical and Electronic Equipment) exports grew in Tennessee and Texas but shrank in the other three states; SIC 10-14 (Mining) grew in Louisiana and Mississippi (0.20 and 0.34, respectively) but declined in Arkansas (-0.13). SIC 34 (Fabricated Metal Products) exports grew in Tennessee and Louisiana but shrank in Arkansas.

Our specification of the gravity model allows an evaluation of the importance of intra-industry trade in the U.S.-Mexico trade relationship. Every state enjoyed increased imports and exports in at least one industry, with five Louisiana industries and eight Tennessee industries showing growth in both imports and exports. SIC 30 (Rubber and Miscellaneous) and SIC 33 (Primary Products) showed both import and export growth in four of the five states. Analysis at the aggregate level would not detect these intraindustry trade patterns or the apparent relocation of production within the five-state region.

\section{REFERENCES}

Anderson, J. and E.V. Wincoop, 2003. "Gravity with Gravitas: A Solution to the Border Puzzle," American Economic Review 93(1), 170-192. 
Baltagi, B.H., 2001. Econometric Analysis of Panel Data. John Wiley \& Sons: New York.

Burfisher, M.E., S. Robinson, and K. Thierfelder, 2001. "The Impact of NAFTA on the United States," Journal of Economic Perspectives 15(1), 125-144.

Chang, I-H. and H.J. Wall, 2004. "Controlling for Heterogeneity in Gravity Models of Trade and Integration," Federal Reserve Bank of St. Louis Working Paper.

Coughlin, C.C. and H.J. Wall, 2003. "NAFTA and the Changing Pattern of State Exports," Papers in Regional Science 82(4), 427-450.

Funk, M, E. Elder, V.W. Yao, and A. Vibhaker, 2006. "Intra-NAFTA Trade and Surface Traffic: A Very Disaggregated View," Federal Reserve Bank of St. Louis Regional Economic Development 2(2), 87-99.

Gonzalez, J. and A. Velez, 1995. "Intra-Industry Trade Between the U.S. and the Major Latin American Countries: Measurement and Implications for Free Trade in the Americas," The International Trade Journal 9(4), 519-536.

Gould, D.M. 1998. "Has NAFTA Changed North American Trade?" Federal Reserve Bank of Dallas Economic Review (First Quarter), 12-23.

Grant, J. and D. Lambert, 2005. "Regionalism in World Agricultural Trade: Lessons from Gravity Model Estimation,” American Agricultural Economics Association Annual Meeting, Providence, Rhode Island.

Klein, M.W., S. Schuh, and R.K. Triest, 2002. "Job Creation, Job Destruction, and International Competition: Job Flows and Trade - The Case of NAFTA," FRB Boston Series, paper no. 02-8.

Krueger, A.O. "Trade Creation and Trade Diversion Under NAFTA." NBER Working Paper No. W7429, National Bureau of Economic Research, December 1999.

Owyang, M., J.M. Piger, and H.J. Wall, 2005. "Business Cycle Phases in U.S. States," Review of Economics and Statistics 87(4), 604-616.

Perot, R. and P. Choate, 1993. "Save Your Job, Save Your Country: Why NAFTA Must Be Stopped Now!" New York: Hyperion.

Shaiken, H., 1993. "Myths About Mexican Workers," Democratic Study Center, Washington, D.C.

U.S. International Trade Commission, U.S. Trade with Mexico during the Third NAFTA Year, 1997, Washington, D.C.

Wall, H.J., 2003. "NAFTA and the Geography of North American Trade." Federal Reserve Bank of St. Louis Review, 85(2), 13-26.

Womack, J.P., 1991. "A Positive Sub Solution: Free Trade in the North American Motor Vehicle Industry," in M.S. Baer and G. Erb (eds.), Strategic Industries in the Mexican-U.S. Free Trade Agreement. Center for Strategic and International Studies: Washington, D.C., 31-65. 